\title{
Grain Protection Potential of Decaleside II, a New Plant-Derived Natural Insecticide
}

\author{
Yallappa Rajashekar*, Thimmappa Shivanandappa \\ Department of Food Protectants and Infestation Control, Central Food Technological Research Institute, \\ (Council of Scientific and Industrial Research), Mysore, India \\ Email: ${ }^{*}$ rajacftri@yahoo.co.in
}

Received 15 April 2014; revised 29 May 2014; accepted 19 June 2014

Copyright (C) 2014 by authors and Scientific Research Publishing Inc.

This work is licensed under the Creative Commons Attribution International License (CC BY).

http://creativecommons.org/licenses/by/4.0/

(c) (i) Open Access

\begin{abstract}
Decaleside II is the novel trisaccharide isolated from the edible roots of Decalepis hamiltonii that belong to a new class of natural insecticides. In the present study we have investigated grain protection potential and persistence activity of Decaleside II against stored-product pests such as Rhyzopertha dominica, Sitophilus oryzae, Tribolium castaneum and Callosobruchus chinensis. Decaleside II usually increased parental mortality and reduced F1 progeny in residual toxicity bioassays. At 7 days of the storage period of treated grains and pulses, the mortality was $100 \%$ of all four stored product insects. Both wheat and green gram treated with Decaleside II were totally free from infestation for the longer period of storage up to $210 \mathrm{~d}$. Decaleside II being a natural trisaccharide, does not pose any toxic hazard from the treated grain and the lack of toxicity is attributed to the $1,4 \alpha$ linkage of the sugars which are easily hydrolyzed by the digestive enzymes such as glucosidases. Therefore, the insect selectivity and mammalian safety of Decaleside II make them highly suitable for use as novel grain protectants of natural origin.
\end{abstract}

\section{Keywords}

Decaleside II, Insecticidal Activity, Grain Protectants, Seed Viability, Mammalian Safety

\section{Introduction}

Stored product insect pests are the major cause of grain losses during post harvest storage, particularly in the tropical countries [1] [2]. It is estimated that more than one-third of the food products are lost to various pests during post-harvest storage [3]. For the control of stored grain insects, several insecticides are used mainly fumigants and residual grain protectants. Although fumigants are generally effective, due to the lack of persistence

\footnotetext{
${ }^{*}$ Corresponding author.
} 
in the treated grain infestation may occur within a few weeks after treatment. Due to extensive use of fumigants, widespread development of resistance has been reported for stored product insects [4]. Although residual grain protectants provide a considerable level of efficacy, there are reports of Sitophilus oryzae, Rhyzopertha dominica and Tribolium castaneum resistant to organophosphates which are commonly used as grain protectants [5]. In view of their health and environmental hazards several chemical pesticides have either been banned or restricted for use in grain protection [4]. There is a need for safer alternatives to conventional chemical insecticides particularly from natural sources, for the protection of grain against insect infestation.

The use of plant products to protect stored grain from insect pest depredation is age-long practice in the world [2] [6] [7]. Essential oils, extracts and its bioactive molecules have been employed greatly in the protection of stored products in many laboratory and field trials [8]-[10]. These essential oils are often used in the control of stored product coleopterans because of their relatively high efficacy against all stages of insects [3] [11]. In many parts world, including India, China and Africa, plant products and its derivatives have been used for grain protection in the small scale [2]. Many of the currently used chemical insecticides such as synthetic pyrethroids were originally derived from the flowers of pyrethrum [12]. Azadirachtin, the active principle from the plant Azadirachta indica (Indian neem), is an insect antifeedant and an insect growth regulator but lacks contact toxicity [13] [14]. Spinosad is a bacterial insecticide, effective against stored product beetle species [15] [16]. At present, there is no effective botanical insecticide to replace pyrethrum for protection of stored grain from insect infestation. Bioinsecticides of plant origin often show selectivity to insect species. They are biodegradable, and have a high chance of acceptability. Therefore, it is considered that plants could be the best source of newer chemical structures for the development of new, eco-friendly, safer insect control agents [8] [17]-[19].

Recently we have reported a new class of natural insecticides from the edible roots of Decalepis hamiltonii named Decalesides [18]. Decalesides (I \& II) are novel trisaccharides that are toxic to various insects and including stored product insects by contact and exhibiting a unique mode of action targeting gustatory sites. Being natural trisaccharides in their chemical nature they could serve as ideal candidates for a grain protectant in view of their eco-friendly structures and mammalian safety aspects. In this study, we have investigated the grain protection potential of Decaleside II against stored-product pests such as Rhyzopertha dominica, Sitophilus oryzae, Tribolium castaneum and Callosobruchus chinensis on infesting wheat (Triticium aestivum) and green gram (Phaseolus aureus Roxb).

\section{Materials and Methods}

\subsection{Insects Rearing}

Cultures of rice weevil, Sitophilus oryzae L. Coleoptera: Curculionidae) and lesser grain borer Rhyzopertha dominica F. (Coleoptera: Bostrichidae) were reared on whole wheat (Triticium aestivum) whereas adzuki bean weevil, Callosobruchus chinensis L. (Coleoptera: Bruchidae) were reared on whole green gram (Phaseolus aureus Roxb) and rust red flour beetle Tribolium castaneum L. (Coleoptera: Bostrichidae) were reared on whole wheat flour. Cultures were maintained at $30^{\circ} \mathrm{C} \pm 1{ }^{\circ} \mathrm{C}$ and $70 \%$ r.h. Adults of $S$. oryzae, T. castaneum ( 3 - $5 \mathrm{~d}$ ) and other species ( $2-3 \mathrm{~d}$ ) were used in the experiments. Experiments were carried out in the laboratory and maintained at $27^{\circ} \mathrm{C} \pm 2^{\circ} \mathrm{C}$ and $70 \% \pm 5 \%$ r.h. [20].

\subsection{Decaleside II}

Decaleside II, the natural insecticide isolated and characterized from methanol extract of root powder of Decalepis hamiltonii, is natural trisaccharide that is highly toxic to stored grain insect pests by contact exposure [18].

\subsection{Insecticidal Effect in Treated Grain}

The Decaleside II, (Decaleside dissolved in 2 milliliter methanol) was applied (spiked) to $50 \mathrm{~g}$ grain, by mixing to give 10, 25, 50, 75 and 100 milligram per kilogram $\left(\mathrm{mg} \cdot \mathrm{kg}^{-1}\right)$. Controls for each set of treatments consisted of grain treated with solvent (methanol) only. 30 unsexed 2 - 3-day-old adults of $C$. chinensis, $R$. dominica and 3 5 -day-old adults of $S$. oryzae, were introduced into the glass jars containing the treated or untreated grains. The glass jars were covered with cotton cloths held with rubber bands. The number of dead insects in each jar was counted after $24 \mathrm{~h}$ and also after $7 \mathrm{~d}$ and the percentage insect mortality was calculated. 


\subsection{Effect of Decaleside II on F1 Progeny}

Grains were treated as described and after $7 \mathrm{~d}$, the insects (dead and live) were removed and the grains were stored under the same experimental conditions until the emergence of F1 progeny. Based on the life cycle of the insect species, the counting period of F1 progeny was established so as to avoid an overlap of generations for each species. At weekly intervals, the F1 progeny was recorded for 8 consecutive weeks. Percentage reduction in adult emergence of $\mathrm{F} 1$ progeny or inhibition rate (\%IR) was calculated as

$$
\% \mathrm{IR}=(\mathrm{Cn}-\mathrm{Tn}) \text { 100/Cn }
$$

where, $\mathrm{Cn}$ is the number of newly emerged insects in the untreated jar and $\mathrm{Tn}$ is the number of insects in the treated jar [20].

\subsection{Seed Germination}

Wheat and green gram seeds were treated with Decaleside II at 100 and $200 \mathrm{mg} \cdot \mathrm{kg}^{-1}$ and germination tests were done at 1 and $90 \mathrm{~d}$ of treatment. Fifty seeds from each treatment were randomly selected from each group and soaked in distilled water for about $30 \mathrm{~min}$, and kept on filter paper (Whatman No. 1) in a petri dish, moistened daily with distilled water and allowed to germinate at room temperature $\left(25^{\circ} \mathrm{C} \pm 2{ }^{\circ} \mathrm{C}\right)$. After $5 \mathrm{~d}$, germinated seeds were counted and percentage germination was calculated [10].

\subsection{Statistical Analysis}

$\mathrm{LC}_{50}$ were determined by Probit analysis [21]. The Mortality data were analyzed using one way analysis of variance (ANOVA) $(\mathrm{P}<0.05)$ by a Newman-Keul's multiple range test using Statplus 2007 software and computer program SAS (version 6.12, SAS Institute Inc. Cory, NC, USA).

\section{Results}

\subsection{Insecticidal Effect of Decaleside II on Treating Grains}

The insect toxicity of Decaleside II in treating grain was dose-dependent, which increased with duration of exposure. The grain (wheat and green gram) treated with the Decaleside II at the $100 \mathrm{mg} \cdot \mathrm{kg}^{-1} 80 \%$ insect mortality was observed at $24 \mathrm{~h}$ (Table 1), mortality reached $100 \%$ mortality at $7 \mathrm{~d}$ of exposure for all the insects (Table 2).

\subsection{Effect of Decaleside II on F1 Progeny}

Dose-dependent reduction in F1 progeny of all the insects in the treated grain was seen and the progeny was completely suppressed at the highest dosage (Table 3). Both wheat and green gram treated with Decaleside II was totally free from infestation for longer duration of storage up to $210 \mathrm{~d}$ (Figure 1).

\subsection{Seed Germination}

Percentage germination of seed in 100 and $200 \mathrm{mg} \cdot \mathrm{kg}^{-1}$ treatments ranged from $92.8 \%$ in the control to $91.1 \%$ in

Table 1. Grain protection potential of Decaleside II: Mortality response of stored-product insect pests on treated wheat grain and green gram at $24 \mathrm{~h}$ exposure.

\begin{tabular}{|c|c|c|c|c|}
\hline \multirow{2}{*}{$\begin{array}{c}\text { Dosage } \\
\left(\mathrm{mg} / \mathrm{kg}^{-1}\right)\end{array}$} & \multicolumn{4}{|c|}{ \%Mortality (mean \pm SE) } \\
\hline & R. dominica & S. oryzae & T. castaneum & C. chinensis \\
\hline 10 & $14.7 \pm 4.1^{\mathrm{a}}$ & $17.7 \pm 1.1^{\mathrm{a}}$ & $7.7 \pm 1.1^{\mathrm{a}}$ & $35.5 \pm 1.5^{\mathrm{a}}$ \\
\hline 25 & $45.6 \pm 4.4^{\mathrm{b}}$ & $34.3 \pm 1.4^{\mathrm{b}}$ & $24.3 \pm 3.3^{\mathrm{b}}$ & $51.6 \pm 1.4^{\mathrm{b}}$ \\
\hline 50 & $64.5 \pm 3.7^{c}$ & $48.3 \pm 1.4^{\mathrm{c}}$ & $36.7 \pm 4.1^{c}$ & $75.8 \pm 0.9^{c}$ \\
\hline 75 & $80.9 \pm 1.7^{\mathrm{d}}$ & $66.4 \pm 1.7^{\mathrm{d}}$ & $49.8 \pm 2.1^{\mathrm{d}}$ & $87.9 \pm 1.5^{\mathrm{d}}$ \\
\hline 100 & $89.9 \pm 1.5^{\mathrm{e}}$ & $74.5 \pm 1^{\mathrm{e}}$ & $68.5 \pm 1.9^{\mathrm{e}}$ & $94.8 \pm 0.9^{\mathrm{e}}$ \\
\hline
\end{tabular}

Values followed by different letters within the vertical columns are significantly different $(\mathrm{P}<0.05)$ by Newman-Keul's multiple range tests. 
Table 2. Grain protection potential of Decaleside II: Mortality response of stored-product insect pests on treated wheat grain and green gram at $7 \mathrm{~d}$ exposure.

\begin{tabular}{ccccc}
\hline \multirow{2}{*}{$\begin{array}{c}\text { Dosage } \\
\left(\mathrm{mg} / \mathrm{kg}^{-1}\right)\end{array}$} & \multicolumn{2}{c}{ \%Mortality (mean $\pm \mathrm{SE})$} \\
\cline { 2 - 4 } & R. dominica & S. oryzae & T. castaneum & C. chinensis \\
\hline $\mathbf{1 0}$ & $20.3 \pm 2.6^{\mathrm{a}}$ & $30.3 \pm 1.6^{\mathrm{a}}$ & $24.3 \pm 2.6^{\mathrm{a}}$ & $43.2 \pm 1.8^{\mathrm{a}}$ \\
$\mathbf{2 5}$ & $61.6 \pm 3.5^{\mathrm{b}}$ & $48.85 \pm 1^{\mathrm{b}}$ & $48.8 \pm 5.1^{\mathrm{b}}$ & $58.8 \pm 0.9^{\mathrm{b}}$ \\
$\mathbf{5 0}$ & $84.9 \pm 4.7^{\mathrm{c}}$ & $72.9 \pm 0.87^{\mathrm{c}}$ & $60.9 \pm 4.8^{\mathrm{c}}$ & $85.1 \pm 1.6^{\mathrm{c}}$ \\
$\mathbf{7 5}$ & $94.3 \pm 1.9^{\mathrm{d}}$ & $87.5 \pm 1.06^{\mathrm{d}}$ & $73.5 \pm 3.6^{\mathrm{d}}$ & $93.5 \pm 0.9^{\mathrm{d}}$ \\
$\mathbf{1 0 0}$ & $100^{\mathrm{e}}$ & $100^{\mathrm{e}}$ & $100^{\mathrm{e}}$ & $100^{\mathrm{e}}$ \\
\hline
\end{tabular}

Values followed by different letters within the vertical columns are significantly different $(\mathrm{P}<0.05)$ by Newman-Keul’s multiple range tests.

Table 3. Grain protection potential of Decaleside II: F1 progeny emergence of stored-product insects in treated grain .

\begin{tabular}{ccccc}
\hline & \multicolumn{3}{c}{ \%Reduction in F1 adult emergence } \\
Dosage $\left(\mathrm{mg} / \mathrm{kg}^{-1}\right)$ & S. oryzae & R. dominica & T. castaneum & C. chinensis \\
\cline { 2 - 4 } 10 & $40.9 \pm 1.4^{\mathrm{a}}$ & $64.2 \pm 4.04^{\mathrm{a}}$ & $36.2 \pm 3.04^{\mathrm{a}}$ & $46.2 \pm 1.7^{\mathrm{a}}$ \\
25 & $54.1 \pm 1.4^{\mathrm{b}}$ & $83.12 \pm 1.9^{\mathrm{b}}$ & $58.1 \pm 2.1^{\mathrm{b}}$ & $57.4 \pm 1.7^{\mathrm{b}}$ \\
50 & $86.3 \pm 1.5^{\mathrm{c}}$ & $92.6 \pm 1.4^{\mathrm{c}}$ & $80.6 \pm 4.1^{\mathrm{c}}$ & $84.9 \pm 0.6^{\mathrm{c}}$ \\
75 & $97.3 \pm 0.21^{\mathrm{d}}$ & $98.3 \pm 0.6^{\mathrm{d}}$ & $88.5 \pm 2.6^{\mathrm{d}}$ & $90.3 \pm 1.4^{\mathrm{d}}$ \\
100 & $100^{\mathrm{e}}$ & $100^{\mathrm{e}}$ & $96.9 \pm 2.2^{\mathrm{e}}$ & $100^{\mathrm{e}}$ \\
\hline
\end{tabular}

*Treated grains were stored for a period of 3 months and weekly emerge of adults counted. Values followed by different letters within the vertical columns are significantly different $(\mathrm{P}<0.05)$ by Newman-Keul's multiple range tests.

the Decaleside II treated wheat grain whereas, in green gram, it ranged from $98 \%$ in the control group to $97 \%$ in the case of Decaleside II (Figure 2). The differences in germination between the control and treated grains were not significant.

\section{Discussion}

Many natural compounds have often been used for crop and food protection. The use of botanicals for the management of the stored grain insect pests is socio economically, and ecofriendlly important [19] [22]. Plant extracts, oils and bioactive molecules may have an important role to play in the preservation of food grains against stored grain insect pests. Earlier studies have reported that, in general, the toxicity of extracts or essential oils isolated from plant samples against stored grain pests related to their major components [8] [10] [17] [18] [23]. Spinosad, a bacterial insecticide, at $1 \mathrm{mg} / \mathrm{kg}$ showed a potent grain protectant against $R$. dominica and $T$. castaneum [15]. However, spinosad degrades under sunlight and loses its activity [24]. The rhizomes of Acorus calamus and the active ingredient ( $\beta$-asarone) have been investigated for their insecticidal properties but the effort to develop $\beta$-asarone as an insecticide received a severe setback with discovery of its mutagenic effect [25]. The seeds of Azadirachta indica have been reported show insecticidal activity against a variety of insect species and, azadirachtin, the active principle, and exhibits insect antifeedant, moult inhibiting and anti-gonadotropic effects in insects [14] [26]. However, its bitter taste and lack of contact toxicity restricts its use and unsuited on stored-products meant for human consumption. We have investigated the insecticidal activity, grain protection potential of Decaleside II against four stored-product insects infesting wheat and green gram. Decaleside II was effective grain protectant.

In this study, we have shown that Decaleside II is an effective grain protectant. Our results showed that the stored product insects (R. dominica, S. oryzae, T. castaneum and C. chinensis) were killed in treated grain (10 $100 \mathrm{mg} \cdot \mathrm{kg}^{-1}$ ) at $24 \mathrm{~h}$ exposure, and the mortality was dose-dependent. The number of adults that emerged from the treated grain after 7 weeks of storage was also dose-dependent $\left(10-100 \mathrm{mg} \cdot \mathrm{kg}^{-1}\right)$ as seen in the reduction of 


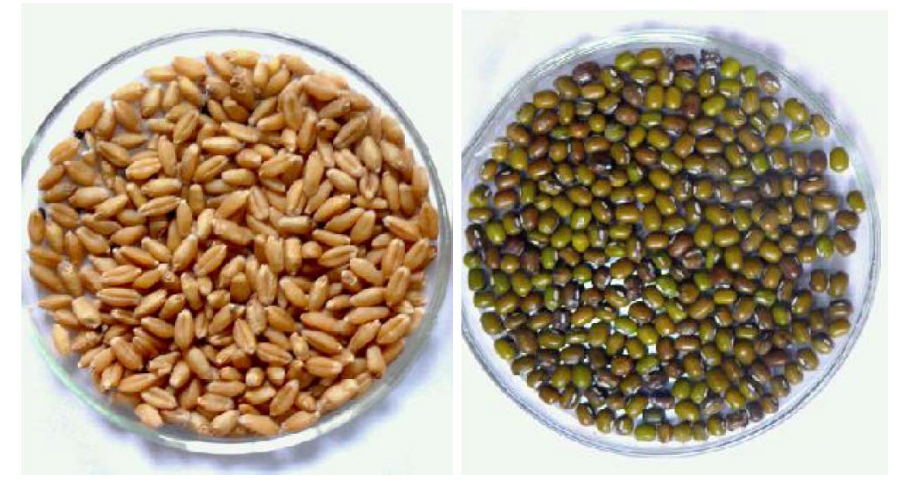

(a)

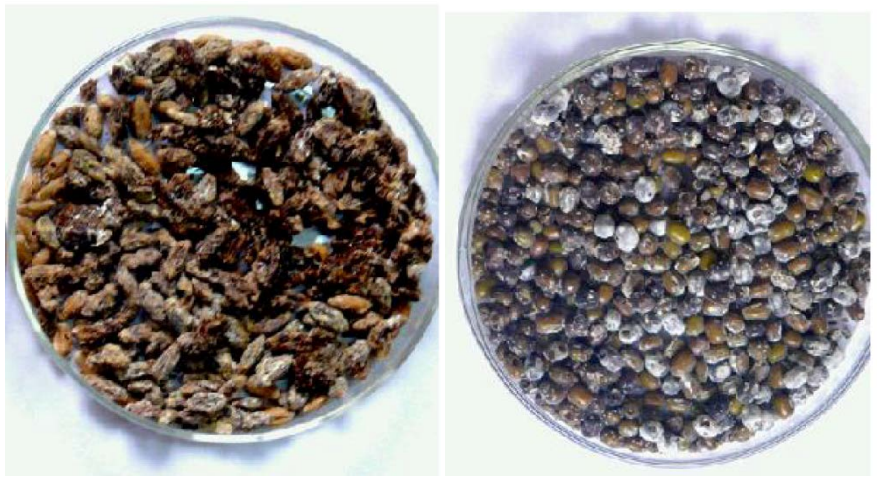

(b)

Figure 1. Grain protection potential of Decaleside II on wheat and green gram. (a) Treated at $0.01 \%\left(100 \mathrm{mg} \cdot \mathrm{kg}^{-1}\right)$ stored for $210 \mathrm{~d}$; (b) Untreated.

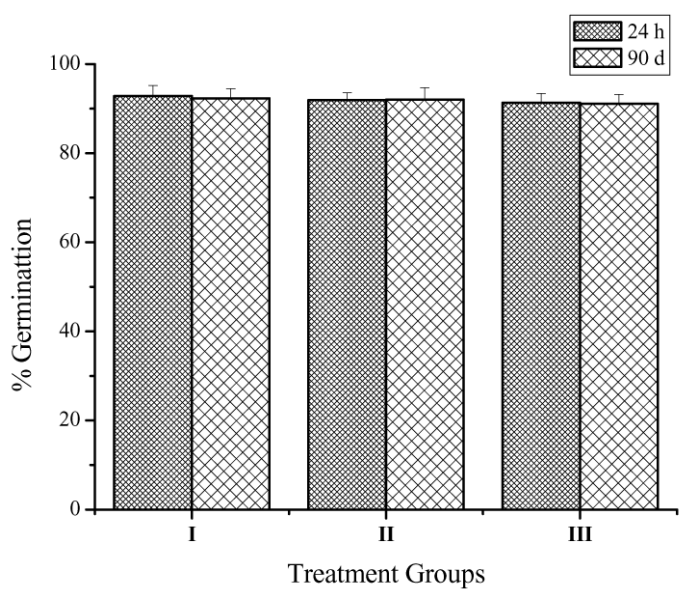

(a)

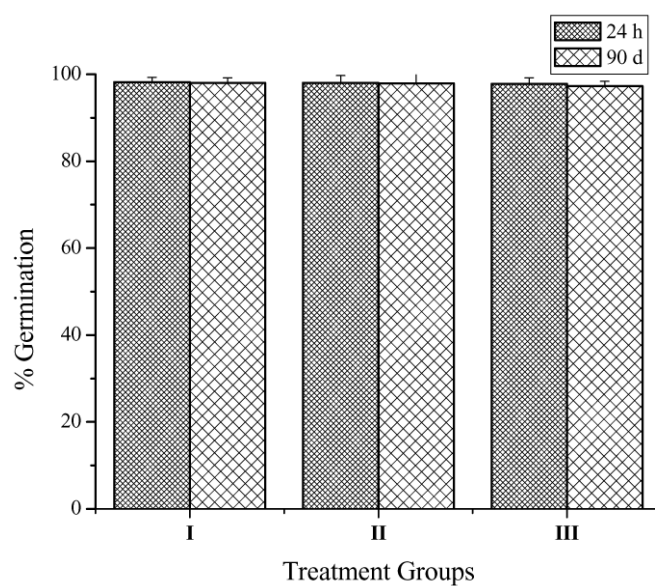

(b)

Figure 2. Effect of Decaleside II on germination of (a) wheat, and (b) green gram. (I) Control; (II) $100 \mathrm{mg} \cdot \mathrm{kg}^{-1}$; (III) $200 \mathrm{mg} \cdot \mathrm{kg}^{-1}$.

F1 progeny. The observed protection of the treated grain from infestation could be due to contact toxicity to adults as well as the larvicidal effect, since adult the emergence was absent in treated grain. Our study shows that the Decaleside II could be effective grain protectant which acts by killing various life stages of stored grain insect pests and total suppression of emergence of progeny in treated grain. The treated grains were totally free from infestation even up to two years of storage, which showed their residual efficacy in the grain protection potential. 
The treatment of the grain (wheat and green gram) with Decaleside II did not show any adverse effect on germination even after 90 days of storage. The tuberous roots of $D$. hamiltonii have been consumed by man for centuries; there is no report of adverse effects on human health. Earlier studies of roots extracts of $D$. hamiltonii have shown no mammalian toxicity in rats in a 90 days study [27]. However, the structure of Decaleside II shows that they are trisaccharides with 1 - 4 linkage. Their lack of toxicity is attributed to the $1,4 \alpha$ linkage of the sugars which are easily hydrolyzed by the digestive enzymes such as glucosidases. Starch and glycogen sugars present in food, which also contain $1-4 \alpha$ linkage are also broken down by the enzymes in the body, and therefore, readily digested. Since, Decaleside II is trisaccharide, it does not pose any toxic hazard from the treated grain. Therefore, the insect selectivity and mammalian safety of Decaleside II makes them highly suitable for use as novel grain protectants of natural origin.

\section{Conclusion}

In summary of this work we have evaluated the grain protection potential of Decaleside II in wheat and green gram. Since Decaleside II is the novel natural insecticide compound and it does not pose any toxic hazard from the treated grain. Therefore, Decaleside II could be considered an ideal grain protectant from the point of view of seed viability and safety to mammals.

\section{Acknowledgements}

The authors wish to thank the Director of the institute for his keen interest in this study; the first author acknowledges the Council of Scientific and Industrial Research, New Delhi, for awarding the Senior Research Fellowship.

\section{References}

[1] Talukder, F.A. (2006) Plant Products as Potential Stored Product Insect Management Agents-A Mini Review. Emirates Journal of Agricultural Science, 18, 17-32.

[2] Rajashekar, Y., Bakthavatsalam, N. and Shivanandappa, T. (2012) Botanicals as Grain Protectants. Psyche, 2012, Article ID: 646740. http://dx.doi.org/10.1155/2012/646740

[3] Tripathi, A.K., Upadhyay, S., Bhuiyan, M. and Bhattacharya, P.R. (2009) A Review on Prospects of Essential Oils as Biopesticides in Insect-Pest Management. Journal of Pharmacology and Phytotherapy, 1, 52-63.

[4] Subramanyam, B. and Hagstrum, D.W. (1995) Resistance Measurement and Management, In: Subramanyam, B. and Hagstrum, D.W., Eds., Integrated Management of Insects in Stored Products, Marcel Dekker, New York, 331-397.

[5] Arthur, F.H. (1996) Grain Protectants: Current Status and Prospects for the Future. Journal of Stored Products Research, 32, 293-302. http://dx.doi.org/10.1016/S0022-474X(96)00033-1

[6] Shaaya, E., Kostjukovaki, M., Eilberg, J. and Sukprakarn, C. (1997) Plant Oil as Fumigants and Contact Insecticides for the Control of Stored-Product Insects. Journal of Stored Products Research, 33, 7-15. http://dx.doi.org/10.1016/S0022-474X(96)00032-X

[7] Ukeh, D.A. (2008) Bioactivities of Essential Oils of Aframomum melegueta and Zingiber officinale Both (Zingiberaceae) against Rhyzopertha dominica (Fabricius). Journal of Entamology, 5, 193-199. http://dx.doi.org/10.3923/je.2008.193.199

[8] Isman, M.B. (2006) Botanical Insecticides, Deterrents and Repellents in Modern Agriculture and an Increasingly Regulated World. Annual Review of Entomology, 51, 45-56. http://dx.doi.org/10.1146/annurev.ento.51.110104.151146

[9] Ravindra, S., Ashok, K., Chandrashekhar, P., Bhawana, S. and Nawal, K.D. (2009) Efficacy of Acorus calamus L. Leaves and Rhizome on Mortality and Reproduction of Callosobruchus chinensis L. (Coleoptera: Bruchidae). Applied Entomology and Zoology, 44, 241-247. http://dx.doi.org/10.1303/aez.2009.241

[10] Rajashekar, Y., Vijay Kumar, H., Ravindra, K.V. and Bakthavatsalam, N. (2013) Isolation and Characterization of Biofumigant from Leaves of Lantana camara for Control of Stored Grain Insect Pests. Industrial Crops and Products, 51, 224-228. http://dx.doi.org/10.1016/j.indcrop.2013.09.006

[11] Rajendran, S. and Sriranjini, V. (2008) Plant Products as Fumigants for Stored-Product Insect Control. Journal of Stored Products Research, 44, 126-135. http://dx.doi.org/10.1016/j.jspr.2007.08.003

[12] Casida, J.E. (1980) Pyrethrum Flowers and Pyrethroid Insecticide. Environmental Health Perspective, 34, $189-202$. http://dx.doi.org/10.1289/ehp.8034189

[13] Islam, M.S. and Talukder, F.A. (2005) Toxic and Residual Effects of Azadirachta indica, Tagets erecta and Cynodon 
dactylon Seed Extracts and Leaf Powder towards Tribolium castaneum. Journal of Plant Disease Protection, 112, 594601.

[14] Morgan, D.E. (2009) Azadirachtin, a Scientific Gold Mine. Bioorganic and Medicinal Chemistry, 17, 4096-4105. http://dx.doi.org/10.1016/j.bmc.2008.11.081

[15] Subramanyam, B., Toews, M.D., Ileleji, K.E., Maier, D.E., Thompson, G.D. and Pitts, T.J. (2007) Evaluation of Spinosad as Grain Protectant on Three Kansas Farms. Crop Protection, 26, 1021-1030. http://dx.doi.org/10.1016/j.cropro.2006.09.011

[16] Vassilakos, T.N., Athanassiou, C.G., Saglam, O., Chloridis, A.S. and Dripps, J.E. (2012) Insecticidal Effect of Spinetoran against Six Major Stored Insect Species. Journal of Stored Products Research, 51, 69-73. http://dx.doi.org/10.1016/j.jspr.2012.06.006

[17] Dayan, F.E., Cantrell, C.L. and Duke, S.O. (2009) Natural Products in Crop Protection. Bioorganic and Medicinal Chemistry, 17, 4022-4034. http://dx.doi.org/10.1016/j.bmc.2009.01.046

[18] Rajashekar, Y., Rao, L.J.M. and Shivanandappa, T. (2012) Decaleside: A New Class of Natural Insecticide Targeting Tarsal Gustatory Sites. Naturwissenschaften, 99, 843-852. http://dx.doi.org/10.1007/s00114-012-0966-5

[19] Miresmailli, S. and Isman, M.B. (2014) Botanical Insecticides Inspired by Plant-Herbivore Chemical Interactions. Trends in Plant Science, 19, 29-35. http://dx.doi.org/10.1016/j.tplants.2013.10.002

[20] Rajashekar, Y., Gunasekaran, N. and Shivanandappa, T. (2010) Insecticidal Activity of the Root Extract of Decalepis hamiltonii against Stored-Product Insect Pests and Its Application in Grain Protection. Journal Food Science and Technology, 43, 310-314.

[21] Finney, D.J. (1971) Probit Analysis. 3rd Edition, Cambridge University Press, Cambridge.

[22] Evergetis, E., Michaelakis, A. and Haroutounian, S.A. (2013) Exploitation of Apiaceae Family Essential Oils as Potent Biopesticides and Rich Source of Phellandrenes. Industrial Crops and Products, 41, 365-370. http://dx.doi.org/10.1016/j.indcrop.2012.04.058

[23] Ebadollahi, A. (2013) Essential Oils Isolated from Myrtaceae Family as Natural Insecticides. Annual Review \& Research in Biology, 3, 148-175.

[24] Liu, T.X., Sparks Jr., A.N., Hendrix III, W.H. and Yue, B. (1999) Effects of SpinTor (Spinosad) on Cabbage Looper (Lepidoptera: Noctuidae) Toxicity and Persistence of Leaf Residue on Cabbage under Field and Laboratory Conditions. Journal of Economic Entomology, 92, 1266-1273.

[25] Abel, G. (1987) Chromosomenschadigende Wiruking von $\beta$-Asarone in Menschlichen Lymphocyten. Planta Medica, 53, 251-253. http://dx.doi.org/10.1055/s-2006-962694

[26] Schmutterer, H. (1990) Properties and Potential of Natural Pesticides from the Neem Tree, Azadirachta indica. Annual Review of Entomology, 35, 271-297. http://dx.doi.org/10.1146/annurev.en.35.010190.001415

[27] Shereen, Ms. (2005) Mammalian Toxicity Assessment and Nutraceutical Properties of the Swallow Root Decalepis hamiltonii. Ph.D. Thesis, University of Mysore. 
Scientific Research Publishing (SCIRP) is one of the largest Open Access journal publishers. It is currently publishing more than 200 open access, online, peer-reviewed journals covering a wide range of academic disciplines. SCIRP serves the worldwide academic communities and contributes to the progress and application of science with its publication.

Other selected journals from SCIRP are listed as below. Submit your manuscript to us via either submit@scirp.org or Online Submission Portal.
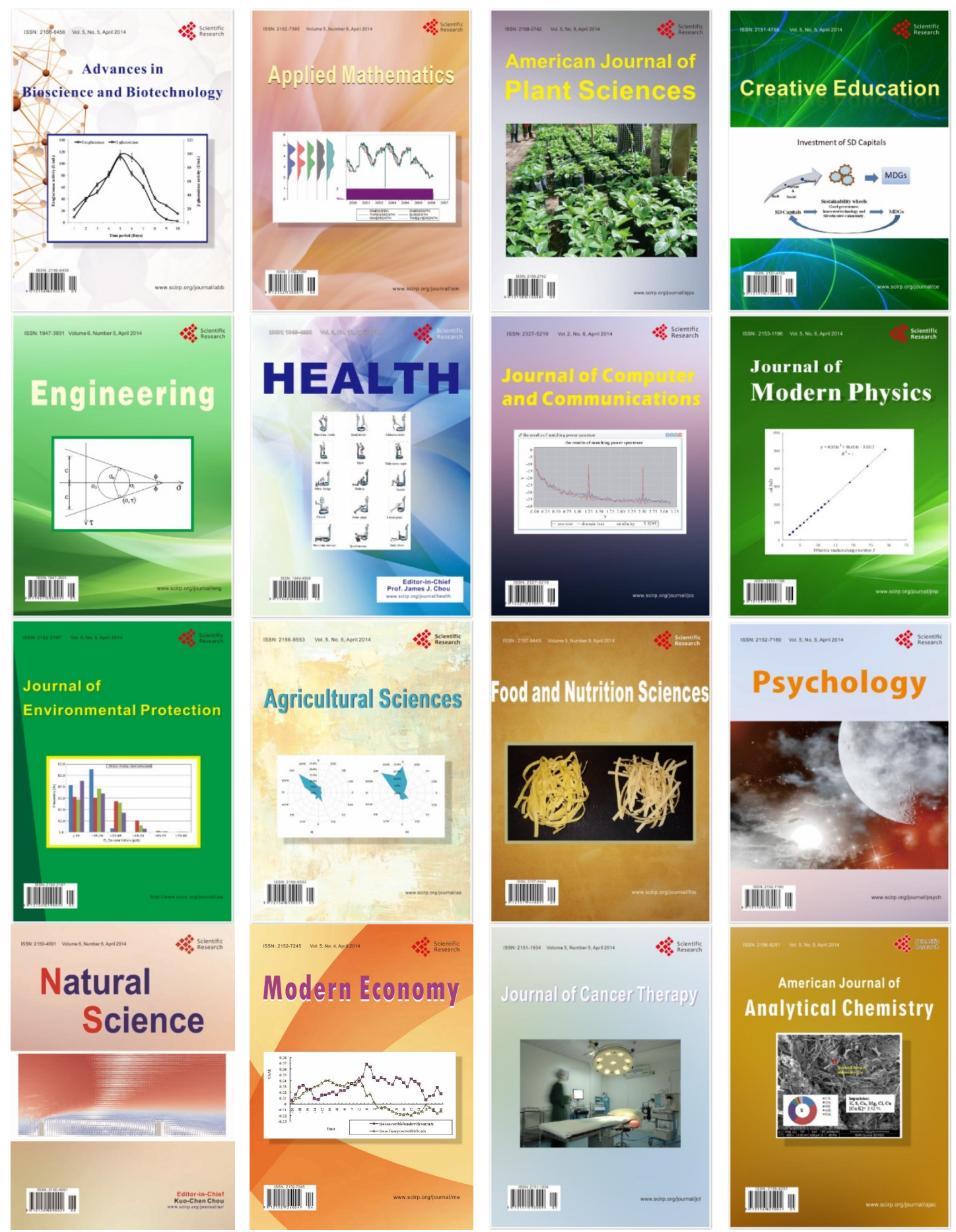